\title{
Does Appliance Design Affect Treatment Outcomes of Class II Division 1 Malocclusion? A Two-Center Retrospective Study
}

\author{
Corresponding Author: \\ Burçin Akan \\ Cemil Meriç Street, 35640, İzmir \\ Turkey \\ Phone: +90 (232) 3254040 \\ Fax: +90 (232) 3252535 \\ E-mail: burcin.yksel@gmail.com
}

Burçin Akan1, Türkan Sezen Erhamza²

${ }^{1}$ Department of Orthodontics, Faculty of Dentistry, Izmir Katip Celebi University, Izmir, Turkey.

${ }^{2}$ Department of Orthodontics, Faculty of Dentistry, Kırıkkale University, Kırıkkale, Turkey.

\begin{abstract}
Objectives: The purpose of this retrospective study was to compare the pre- and post-treatment values of patients treated with monoblock and twin-block appliances with the values of the skeletal Class I individuals.

Material and Methods: The initial lateral cephalometric radiographs of the pubertal untreated skeletal class I patients and cephalometric radiographs of 60 (30 monoblock, 30 twin-block) patients before and after the functional treatment were included in the study. Skeletal, dental, and soft tissue measurements were performed by a single researcher using Dolphin Imaging software version 11.95 (Dolphin Imaging, Chatsworth, CA, USA). Paired t-test was used for statistical evaluation and $\mathrm{P}<0.05$ was considered statistically significant.

Results: In both monoblock and twin-block groups, there was a statistically significant increase in the measurements of the lower jaw and the vertical direction values (sella nasion B point (SNB), pogonion nasion perpendicular, Y-axis, sella nasiongonion gnathion, palatal-mandibular angle, anterior facial height, mandibular length $\mathrm{P}<0.05$ ); however, in the Twin-block group, the lower jaw was found to be displaced more forward (change for twin-block; SNB = 2.35, Wits appraisal = -4.77 ). The most measurements of the twin-block treated group were similar to the control group.

Conclusions: Both functional appliances have been identified to be useful in achieving treatment targets; however, with twinblock, results closer to ideal values are obtained.
\end{abstract}

Keywords: growth and development; mandible; orthodontics; retrognathia; treatment outcome.

Accepted for publication: 12 May 2021

To cite this article:

Akan B, Erhamza TS.

Does Appliance Design Affect Treatment Outcomes of Class II Division 1 Malocclusion? A Two-Center Retrospective Study J Oral Maxillofac Res 2021;12(2):e4

URL: http://www.ejomr.org/JOMR/archives/2021/2/e4/v12n2e4.pdf

doi: $10.5037 /$ jomr.2021.12204 


\section{INTRODUCTION}

Twenty-seven percent of orthodontic malocclusions have been reported to be Class II [1]. There are studies reporting the ratio to vary between $4.97 \%$ and $40 \%$ in Turkey [2]. For this type of malocclusion, recognized in one of four children, the question whether the individual also has a skeletal problem should be addressed. Although there are several alternatives for the solution of dental problems, timing of the solution of skeletal problems and adaptation of the patient to the mechanics to be selected improve the clinical success. Mossey [3] Class II anomaly aetiology has been suggested to be multifactorial Anomalies might result from genetic, racial, familial, or environmental factors, or a combination of all [4]. In individuals with skeletal class II structure, the problem may be caused by the combination of the problem in the upper jaw, lower jaw, or both. When a skeletal problem is detected, treatment approach usually involves the correction of the deviation from the ideal situation. Some researchers have reported that the anomaly is mostly caused by mandibular retrusion [5-8]. Sayın and Türkkahraman [9] reported the mandibula to be small in size, located posteriorly and to represent a posterior rotation model in their study involving adults with Class II division 1 anomaly. In their study, Akarsu and Kocadereli [10] examined the cephalometric morphology of Turkish children with Class II anomaly and found the anomaly to be caused by mandibular retrusions and represent a dolichofacial model.

Mandibular retrusions has been reported to result from posteriorly positioned glenoid fossa compared to sella turcica, shorter ramus length, increased gonial angle, teeth contact and abnormal contraction pattern of the muscles $[11, \underline{12}]$.

Various functional orthopaedic appliances have been used in the treatment of skeletal Class II anomaly during the growth and development period $[\underline{4}, 13, \underline{14}]$.

Functional orthopaedic treatment involves changes in the sagittal and vertical position of the mandible as a result of the transfer of the natural forces produced during the functional activities of the individuals by the muscles and soft tissues around the oral cavity by means of functional appliances to the tooth and jaw [15]. Monoblock (MB), activator, bionator, frankel II, mandibular advancement device and twin-block (TB) appliances among removable functional appliances are used in the treatment of anomalies of Class II division $1[\underline{14}, \underline{15}]$.

By anterior positioning of the MB and the mandible, all chewing muscles except musculus pterygoideus lateralis are prolonged. The muscles trying to return to their former position, apply backward force to the lower jaw. This force pushes the upper jaw teeth in the posterior direction by means of the MB acrylic and forces the upper jaw teeth move in the distal direction. Thus, while the forward development of the maxilla is blocked, the forward development of the mandible is stimulated [16]. Considering the dentoalveolar effects of the device, it has been associated with protrusion in the lower incisors and retrusion in upper incisors [17-20]. In addition, it has been identified to result in clockwise rotation in the occlusal plane as it causes eruption of the mandibular posterior teeth and maxillary anterior teeth while preventing the eruption of maxillary posterior teeth and mandibular anterior teeth. Hence, the occlusal plane angle has been observed to be increased and the Class II relationship to be improved [20].

TB appliance is a functional appliance consisting of two separate parts: upper and lower. During mandibular closing, opposing surfaces guide each other to close the lower jaw to the front [21]. In studies of this subject, TB appliance was found to displace the mandible forward with respect to the skull base, increase the mandibular sagittal development, inhibit the maxillary sagittal development, increase mandibular length, cause lower incisor protrusion, upper incisor retrusion, upper molar distalization and lower molar mesialization [17,22-25].

Designing the most effective functional appliance since the 1800's is a controversial issue. There are several studies in the literature comparing the effects of different functional appliances; however, no consensus achieved [13, 16-18, 23-25].

The differences between the design of $\mathrm{MB}$ and $\mathrm{TB}$ appliances are thought to affect the comfort and wear time of the patient. The aim of this retrospective study is based on this idea; to compare the early effects of monoblock and twin-block appliances used for the treatment of patients with Class II division 1 malocclusion on skeletal and dentoalveolar structures and to compare the results with those of skeletal Class I individuals. Two hypotheses have been tested in the present study: functional appliances with two different designs have effects on skeletal and dentoalveolar structures and, treatment results obtained with functional appliance are similar to those of patients with skeletal Class I properties.

\section{MATERIAL AND METHODS}

Our study involved the cephalometric radiographs of the patients treated with $\mathrm{MB}$ and $\mathrm{TB}$ appliance 
in Department of Orthodontics of the Faculty of Dentistry of Izmir Katip Celebi University and to the Orthodontics Department of the Faculty of Dentistry of the Kirlkkale University. This two-center retrospective study protocol was approved by the Ethical Committee of Izmir Katip Celebi University, Turkey (Protocol No: 281, Date: 08.08.2019). This study was conducted from August 8, 2019 to July 15, 2020 .

\section{Inclusion criteria}

For the TB and MB groups, pre- and post-treatment lateral cephalometric radiographs of patients with angle Class II part 1, overjet greater than $4 \mathrm{~mm}$, A point nasion $\mathrm{B}$ point (ANB) angles greater than $4^{\circ}$, mandibular retrognathia in sagittal skeletal Class II relationship and normal or decreased vertical direction growth pattern were included. The comparison of the initial lateral cephalometric values of the patients treated with two appliances is presented in Table 1.

For the control group, the initial lateral cephalometric radiographs of patients with skeletal and dental Class I, normal growth pattern and minimal inclination were included in the study.

\section{Exclusion criteria}

Systemic disease, orthodontic treatment history, congenital tooth defect or permanent tooth extraction, severe facial asymmetry, increased vertical direction growth pattern and bad radiography image quality were the exclusion criteria.

The average chronological age of the patients was 12 (SD 1.03) years. The stages of growth were determined according to the wrist radiographs: 14 of them were $\mathrm{SH} 2$ (appearance of ulnar sesamoid at metacarpophalangeal joint of the first finger and hooking of hamate stage 2), 38 were MP3 cap (middle phalanx of the third finger; epiphysis caps its diaphysis) and 8 were DP3u (distal phalanx of the third finger; complete epiphyseal union) stage. Patients were instructed to wear the appliance all day except meals. Appliance was used until dental class I or super class I molar relationship was obtained. After obtaining the appropriate molar relationship, lateral cephalometric radiographs of the patient were obtained. In MB group, the average period of appliance use was 8.7 months while it was 9.3 months in TB group. Skeletal, dental and soft tissue measurements were performed by 90 subjects, 30 of whom were treated with a MB appliance, 30 of whom were treated with a TB appliance, and 30 of the control group, were included in the study. All participants read and signed the informed consent form.

Dolphin Imaging software version 11.95 (Dolphin Imaging, Chatsworth, CA, USA) by a single researcher using pre- and post-treatment lateral cephalometric radiographs. The landmarks used in the analysis of skeletal, dental and soft tissue measurements are shown in Figure 1.

\section{Statistical analysis}

The data were evaluated in IBM SPSS Statistics 20.0 (IBM Corp., Armonk, New York, USA) statistical package program. Descriptive statistics were presented as mean and standard deviation (M [SD]). Normal distribution of numerical variables was evaluated by Shapiro Wilk normality test and Q-Q graphs. Paired t-test and ANOVA test were used for multiple comparisons of the groups. $\mathrm{P}<0.05$ was considered statistically significant

All cephalometric measurements were conducted by a examiner (B.A.) The measurements were performed again on randomly selected 10 cephalograms by the same examiner after two weeks. According to the intraclass correlation data (ICC), which were evaluated for consistency and reproducibility of the measurements, $\geq 90 \%$ correlation was obtained between two measurements. The results of the intraclass correlation analysis related to the methodological errors showed the measurements not to affect the results and to be repeated with a nonsignificant error. In the post-hoc power analysis test related to the sample size using the G*Power version 3.1.9.2 (Heinrich-Heine-Universität, Düsseldorf, Germany) program, the effect size was found to be 0.8 , with a $95 \%$ confidence level. The power of the study was approximately 0.86 .

\section{RESULTS}

Pre- and post-cephalometric changes of patients in both groups are given in Table 1. Both hypotheses were partially accepted.

When initial cephalometric values were compared, it was found that the skeletal vertical values in the TB group were statistically lower than the MB group (decreased vertical direction pattern; Y-axis, palatal-mandibular angle (PP-MP), sum total, sella-gonion (S-Go), posterior facial height/ anterior facial height, midface and mandibular length $\mathrm{P}<0.05)$ and soft tissues were observed to be more backward (nasolabial angle, upper lip-E plane (UL-E), upper lip anterior, soft tissue A, soft tissue B point (ST B') and pogonion ( $\mathrm{Pg}) \mathrm{P}<0.05)$. 
Table 1. Comparison of dental, skeletal and soft tissue measurements between pre-treatment (T0) and post-treatment (T1) in each groups

\begin{tabular}{|c|c|c|c|c|c|c|c|}
\hline & \multicolumn{3}{|c|}{ Monoblock } & \multicolumn{3}{|c|}{ Twin-block } & \multirow{3}{*}{$\mathbf{P}^{\mathbf{b}}$} \\
\hline & T0 & $\mathrm{T} 1$ & \multirow[b]{2}{*}{$\mathbf{P}$} & T0 & $\mathrm{T} 1$ & \multirow{2}{*}{$\mathbf{P}$} & \\
\hline & Mean (SD) & Mean (SD) & & Mean (SD) & Mean (SD) & & \\
\hline \multicolumn{8}{|l|}{ Maxillary anteroposterior skeletal } \\
\hline SNA $\left({ }^{\circ}\right)$ & $79.36(2.93)$ & $79.39(3.09)$ & $0.000^{\mathrm{a}}$ & $80.27(3.37)$ & $80.5(3.9)$ & $0.000^{\mathrm{a}}$ & 0.269 \\
\hline A-Na Perp. (mm) & $-0.56(2.58)$ & $-0.06(3.35)$ & $0.000^{\mathrm{a}}$ & $0.53(2.87)$ & $-0.17(3.12)$ & $0.000^{\mathrm{a}}$ & 0.127 \\
\hline Co-A (mm) & $73.2(6.36)$ & $75.88(7.03)$ & $0.000^{\mathrm{a}}$ & $81.65(5.13)$ & $82.58(4.72)$ & $0.000^{\mathrm{a}}$ & $0.000^{2}$ \\
\hline \multicolumn{8}{|l|}{ Mandibular anteroposterior skeletal } \\
\hline $\mathrm{SNB}\left({ }^{\circ}\right)$ & $74.13(2.68)$ & $75.06(3.4)$ & $0.000^{\mathrm{a}}$ & $74.4(2.5)$ & $76.76(2.94)$ & $0.000^{\mathrm{a}}$ & 0.684 \\
\hline Pg-Na Perp. (mm) & $-7.72(4.57)$ & $-5.74(6.57)$ & $0.000^{\mathrm{a}}$ & $-6.42(4.76)$ & $-4.66(5.65)$ & $0.001^{\mathrm{a}}$ & 0.282 \\
\hline Co-Gn (mm) & $92.73(8.14)$ & $99.01(8.91)$ & $0.000^{\mathrm{a}}$ & $101.21(6.69)$ & $107.15(7)$ & $0.000^{\mathrm{a}}$ & $0.000^{2}$ \\
\hline \multicolumn{8}{|l|}{ Intermaxillary } \\
\hline $\operatorname{ANB}\left(^{\circ}\right)$ & $5.23(1.75)$ & $4.32(2.09)$ & $0.000^{\mathrm{a}}$ & $5.84(2.12)$ & $3.75(2.57)$ & $0.000^{\mathrm{a}}$ & 0.228 \\
\hline Wits (mm) & $3.74(2.44)$ & $2.15(2.39)$ & $0.000^{\mathrm{a}}$ & $5.80(2.36)$ & $1.03(2.85)$ & $0.011^{\mathrm{a}}$ & 0.002 \\
\hline Co-Gn - Co-A (mm) & $19.55(3.4)$ & $23.12(3.89)$ & $0.000^{\mathrm{a}}$ & $19.56(3.09)$ & $24.59(4.49)$ & $0.001^{\mathrm{a}}$ & 0.987 \\
\hline \multicolumn{8}{|l|}{ Vertical skeletal } \\
\hline SGn-FH $\left({ }^{\circ}\right)$ & $60.35(2.95)$ & $60.07(3.75)$ & $0.000^{\mathrm{a}}$ & $58.42(3.26)$ & $58.67(3.3)$ & $0.000^{\mathrm{a}}$ & $0.02^{\mathrm{a}}$ \\
\hline SN-GoGn $\left({ }^{\circ}\right)$ & $31.91(5.24)$ & $32.37(5.72)$ & $0.000^{\mathrm{a}}$ & $30.03(5.18)$ & $29.7(5.23)$ & $0.000^{\mathrm{a}}$ & 0.167 \\
\hline FMA $\left(^{\circ}\right)$ & $21.88(4.64)$ & $21.76(5.45)$ & $0.000^{\mathrm{a}}$ & $19.73(5.39)$ & $20.39(4.83)$ & $0.000^{\mathrm{a}}$ & 0.105 \\
\hline SN-PP $\left({ }^{\circ}\right)$ & $8.3(3.12)$ & $9.06(3.32)$ & $0.000^{\mathrm{a}}$ & $8.65(4.02)$ & $8.04(4.37)$ & $0.000^{\mathrm{a}}$ & 0.708 \\
\hline PP-MP $\left({ }^{\circ}\right)$ & $26.51(4.97)$ & $26.29(5.05)$ & $0.000^{\mathrm{a}}$ & $23.22(5.61)$ & $23.65(4.96)$ & $0.000^{\mathrm{a}}$ & $0.02^{\mathrm{a}}$ \\
\hline N-S-Art + S-Art-Go + Art-Go-Me $\left({ }^{\circ}\right)$ & $394.8(5.45)$ & $395.35(5.82)$ & $0.000^{\mathrm{a}}$ & $391.87(5.19)$ & $391.7(5.29)$ & $0.000^{\mathrm{a}}$ & $0.037^{2}$ \\
\hline S-Go $(\mathrm{mm})$ & $65.21(5.52)$ & $70.12(7.39)$ & $0.000^{\mathrm{a}}$ & $70.85(6.34)$ & $75.45(7.05)$ & $0.000^{\mathrm{a}}$ & $0.001^{2}$ \\
\hline ANS-Me (mm) & $56.41(5.22)$ & $60.72(5.81)$ & $0.000^{\mathrm{a}}$ & $58.11(5.27)$ & $62.04(4.82)$ & $0.000^{\mathrm{a}}$ & 0.214 \\
\hline NA-APg $\left({ }^{\circ}\right)$ & $8.93(4.95)$ & $6.83(5.75)$ & $0.000^{\mathrm{a}}$ & $9.18(5.5)$ & $5.33(6.23)$ & $0.000^{\mathrm{a}}$ & 0.854 \\
\hline PFH/AFH (\%) & $64.34(4.47)$ & $66.41(4.7)$ & 0.883 & $67.49(4.74)$ & $68.46(5.2)$ & $0.03^{\mathrm{a}}$ & $0.01^{\mathrm{a}}$ \\
\hline SN-maxillary occlusal plane & $17.54(5.45)$ & $18.21(5.607)$ & $0.000^{\mathrm{a}}$ & $14.98(4.29)$ & $16.84(4.03)$ & $0.000^{\mathrm{a}}$ & 0.049 \\
\hline \multicolumn{8}{|l|}{ Maxillary dentoalveolar } \\
\hline $\mathrm{U} 1-\mathrm{SN}\left({ }^{\circ}\right)$ & $101.44(10.41)$ & $102.77(6.77)$ & $0.000^{\mathrm{a}}$ & $104.69(12.43)$ & $101.22(9.28)$ & $0.000^{\mathrm{a}}$ & 0.278 \\
\hline $\mathrm{U} 1-\mathrm{C}$ & $118.97(7.26)$ & $121(5.48)$ & 0.099 & $119.67(11.24)$ & $118.85(7.37)$ & $0.002^{\mathrm{a}}$ & 0.776 \\
\hline $\mathrm{U} 1-\mathrm{PP}\left({ }^{\circ}\right)$ & $109.73(9.74)$ & $111.83(5.84)$ & $0.001^{\mathrm{a}}$ & $113.31(13.58)$ & $109.27(9.54)$ & $0.000^{\mathrm{a}}$ & 0.246 \\
\hline U1-I & $22.08(9.66)$ & $23.39(6.18)$ & $0.000^{\mathrm{a}}$ & $24.43(13.12)$ & $20.75(10.09)$ & $0.000^{\mathrm{a}}$ & 0.433 \\
\hline U1-NA (mm) & $3.69(3.34)$ & $4.12(2.38)$ & $0.000^{\mathrm{a}}$ & $4.16(3.78)$ & $3.18(3.26)$ & $0.000^{\mathrm{a}}$ & 0.612 \\
\hline U1-I & $25.24(2.46)$ & $26.52(2.9)$ & $0.000^{\mathrm{a}}$ & $25.07(3.16)$ & $26.21(2.6)$ & $0.000^{\mathrm{a}}$ & 0.817 \\
\hline U6-NF (mm) & $17.46(1.7)$ & $18.63(2.15)$ & $0.001^{\mathrm{a}}$ & $18.77(2.16)$ & $19.30(2.55)$ & $0.001^{\mathrm{a}}$ & $0.011^{2}$ \\
\hline \multicolumn{8}{|l|}{ Mandibular dentoalveolar } \\
\hline L1-MP $\left({ }^{\circ}\right)$ & $97.01(5.56)$ & $99.17(5.5)$ & $0.000^{\mathrm{a}}$ & $97.38(6.76)$ & $100.18(6.36)$ & $0.000^{\mathrm{a}}$ & 0.818 \\
\hline L1-NB $\left({ }^{\circ}\right)$ & $25.95(6.23)$ & $29.58(5.67)$ & $0.000^{\mathrm{a}}$ & $23.67(6.98)$ & $27.3(10.23)$ & $0.017^{\mathrm{a}}$ & 0.187 \\
\hline L1-NB (mm) & $4.06(2.23)$ & $5.59(2.07)$ & $0.000^{\mathrm{a}}$ & $4.06(2.23)$ & $5.81(2.21)$ & $0.000^{\mathrm{a}}$ & 0.995 \\
\hline L1-A & $0.33(2.15)$ & $2.3(2.03)$ & $0.000^{\mathrm{a}}$ & $-0.56(2.38)$ & $2.63(2.53)$ & $0.000^{\mathrm{a}}$ & 0.134 \\
\hline L1-N & $30.82(2.97)$ & $32.64(3.63)$ & $0.000^{\mathrm{a}}$ & $34.93(3.12)$ & $34.91(2.62)$ & $0.002^{\mathrm{a}}$ & $0.000^{2}$ \\
\hline L6-MP (mm) & $21.6(2.47)$ & $23.55(2.6)$ & $0.000^{\mathrm{a}}$ & $24.95(2.82)$ & $27.95(5.07)$ & 0.289 & $0.000^{2}$ \\
\hline \multicolumn{8}{|l|}{ Interdental } \\
\hline Ove & $6.31(2.74)$ & $4.31(1.64)$ & $0.000^{\mathrm{a}}$ & $7.65(2.8)$ & $2.76(1.44)$ & 0 & 0.065 \\
\hline Over & $3.91(1.93)$ & $2.34(2.12)$ & $0.001^{\mathrm{a}}$ & $4.3(2.12)$ & $0.64(2.1)$ & $0.045^{\mathrm{a}}$ & 0.463 \\
\hline Interincisal angle (U1-L1) $\left(^{\circ}\right)$ & $126.75(10.87)$ & $122.69(7.57)$ & $0.001^{\mathrm{a}}$ & $126.07(15.93)$ & $126.51(10.68)$ & $0.000^{\mathrm{a}}$ & 0.846 \\
\hline \multicolumn{8}{|l|}{ Soft-tissue profile } \\
\hline Nasolabial angle $\left({ }^{\circ}\right)$ & $110.12(8.95)$ & $109.72(9.41)$ & $0.000^{\mathrm{a}}$ & $119.47(9.99)$ & $119.50(12.35)$ & $0.027^{\mathrm{a}}$ & $0.000^{2}$ \\
\hline Nasal projection $(\mathrm{mm})$ & $11.64(1.66)$ & $12.61(1.86)$ & $0.000^{\mathrm{a}}$ & $12.33(3.1)$ & $13.83(2.04)$ & $0.001^{\mathrm{a}}$ & 0.291 \\
\hline Lower lip to E-plane (mm) & $0.69(2.89)$ & $0.34(2.75)$ & $0.000^{\mathrm{a}}$ & $-0.59(2.99)$ & $-1.41(2.85)$ & $0.000^{\mathrm{a}}$ & 0.097 \\
\hline Upper lip to E-plane (mm) & $0.39(1.92)$ & $-1.31(1.91)$ & $0.000^{\mathrm{a}}$ & $-0.91(2.92)$ & $-3.22(2.88)$ & $0.001^{\mathrm{a}}$ & $0.047^{\circ}$ \\
\hline Upper lip anterior (ULA-Sn) (mm) & $2.3(1.83)$ & $1.86(2.13)$ & $0.000^{\mathrm{a}}$ & $0.26(3.03)$ & $0.06(2.64)$ & $0.004^{\mathrm{a}}$ & 0.003 \\
\hline Lower lip anterior (LLA-Sn) (mm) & $-3.62(2.65)$ & $-2.86(3.08)$ & $0.000^{\mathrm{a}}$ & $-6.59(5)$ & $-4.26(4)$ & $0.007^{\mathrm{a}}$ & $0.006^{2}$ \\
\hline Soft tissue A point' (A'-Sn) (mm) & $-1.01(1.17)$ & $-1.49(1.36)$ & $0.000^{\mathrm{a}}$ & $-1.97(2.19)$ & $-2.17(1.92)$ & $0.03^{\mathrm{a}}$ & $0.04^{\mathrm{a}}$ \\
\hline Soft tissue B point' (B'-Sn) (mm) & $-11.73(2.89)$ & $-11.35(3.47)$ & $0.000^{\mathrm{a}}$ & $-15.26(6.6)$ & $-12.03(5.43)$ & $0.07^{\mathrm{a}}$ & $0.01^{\mathrm{a}}$ \\
\hline Soft tissue pogonion (Pg'-Sn) (mm) & $-9.8(3.21)$ & $-9.31(4.47)$ & $0.000^{\mathrm{a}}$ & $-13.8(7.65)$ & $-11.33(6.77)$ & $0.008^{\mathrm{a}}$ & 0.012 \\
\hline Soft tissue convexity $\left({ }^{\circ}\right)$ & $127.42(3.92)$ & $127.9(4.27)$ & $0.000^{\mathrm{a}}$ & $125.07(10.35)$ & $126.4(8.6)$ & 0.518 & 0.251 \\
\hline
\end{tabular}

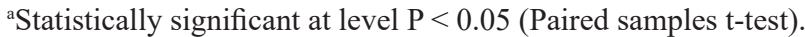

${ }^{\mathrm{b}}$ Comparison of initial cephalometric measurements between monoblock and twin-block groups.

$\mathrm{S}=$ sella; $\mathrm{N}=$ nasion; $\mathrm{A}=\mathrm{A}$ Point (subspinale); $\mathrm{B}=\mathrm{B}$ point (supramentale); $\mathrm{SNA}=$ sella-nasion- $\mathrm{A}$ point angle; $\mathrm{SNB}=$ sella-nasion-B point angle; $\mathrm{ANB}=\mathrm{A}$ point-nasion-B point angle; $\mathrm{Na}$ Perp = nasion perpendicular; $\mathrm{Pg}=$ pogonion; $\mathrm{Gn}=$ gnathion; $\mathrm{FH}=\mathrm{Frankfurt} \mathrm{horizontale}$; $\mathrm{Go}=$ gonion; $\mathrm{PP}=$ palatal plane; $\mathrm{MP}=$ mandibular plane; $\mathrm{Art}=$ articulare; $\mathrm{Me}=$ menton; $\mathrm{ANS}=$ anterior nasal spine; $\mathrm{Co}=\mathrm{condylion}$; $\mathrm{Mx} / \mathrm{Md}$ dif $=$ maxillomandibular difference; $\mathrm{PFH}=$ posterior facial height; $\mathrm{AFH}=$ anterior facial height; $\mathrm{OCP}=\mathrm{occlusal}$ plane; $\mathrm{U} 1=$ incisal edge of the maxillary incisor; L1 = incisal edge of the mandibular incisor; U6 = maxillary first molar; L6 = mandibular first molar; $\mathrm{NF}=$ nasal floor; $\mathrm{Sn}=$ subnasale; $\mathrm{ULA}=$ upper lip anterior; $\mathrm{LLA}=$ lower lip anterior; $\mathrm{A}^{\prime}$ = soft tissue subspinale; $\mathrm{B}^{\prime}=$ soft tissue supramentale; $\mathrm{Pg}^{\prime}=$ soft tissue pogonion. 


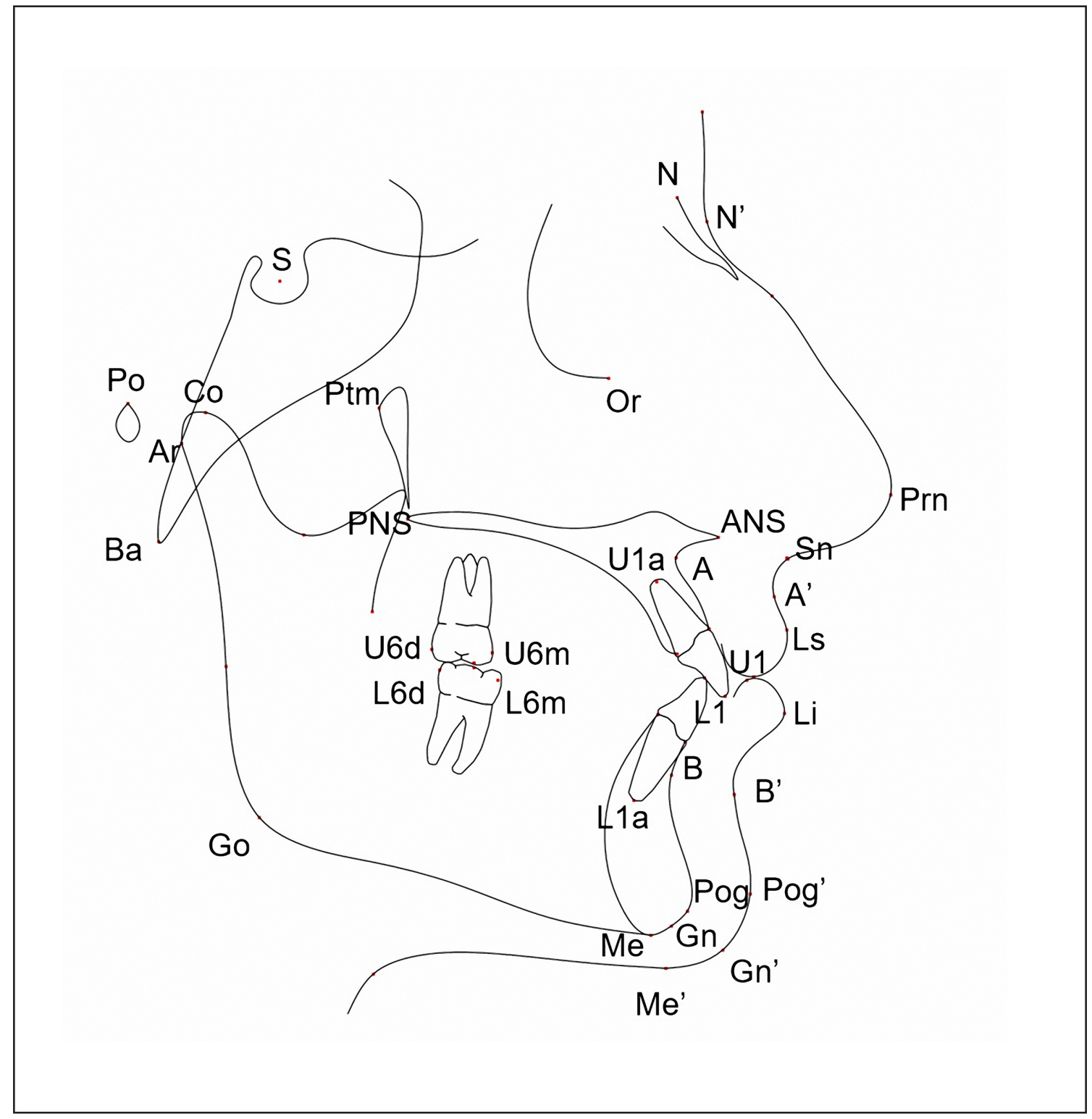

Figure 1. Cephalometric points: $\mathrm{S}=$ sella; $\mathrm{N}=$ nasion; $\mathrm{N}^{\prime}=$ soft tissue nasion; $\mathrm{Po}=$ porion; $\mathrm{Or}=$ orbitale; $\mathrm{Co}=$ condylion; $\mathrm{Ba}=$ basion; $\mathrm{Ar}=$ articulare; $\mathrm{ANS}=$ anterior nasal spine; $\mathrm{PNS}=$ posterior nasal spine; $\mathrm{A}=$ subspinale; $\mathrm{A}^{\prime}=$ soft tissue subspinale; $\mathrm{B}=$ supramentale; $\mathrm{B}^{\prime}=$ soft tissue supramentale; $\mathrm{Me}=$ mentalis; $\mathrm{Me}$ ' = soft tissue mentalis; $\mathrm{Go}=$ gonion; $\mathrm{Gn}=$ gnathion; $\mathrm{Gn}$ ' = soft tissue gnathion; $\mathrm{Pg}=$ pogonion; $\mathrm{Pg}^{\prime}=$ soft tissue pogonion; $\mathrm{Sn}=$ subnasale; $\mathrm{Ls}=$ labialis superior; $\mathrm{Li}=$ labialis inferior; $\mathrm{U} 1$ = incisal edge of the maxillary incisor; $\mathrm{U} 1 \mathrm{a}=$ apex of the maxillary incisor; L1 = incisal edge of the mandibular incisor; L1a = apex of the mandibular incisor; U6m $=$ mesiobuccal cusp of the maxillary first molar; U6d = distobuccal cusp of the maxillary first molar; L6m = mesiobuccal cusp of the mandibular first molar; L6d = distobuccal cusp of the mandibular first molar.

For both appliances, statistically significant skeletal, dental, and soft tissue changes were found between pre- and post-treatment measurements. When treatment results of both groups were compared (T1T0: difference) sella nasion B point (SNB), lower1-A point pogonion ( $\mathrm{L} 1-\mathrm{APg}$ ) and ST B', ANB, A pointnasion perpendicular (A-Na Per), sella nasion-palatal plane (SN-PP), upper1-sella nasion (U1-SN), upper1palatal plane (U1-PP), upper1-nasion A point (U1NA), convexity angle and overbite values were found to be significantly different $\mathrm{P}<0.05$. The treatment results of the groups are presented in Table 2 .

The comparison of post-treatment values of $\mathrm{TB}$ and $\mathrm{MB}$ groups with the control group revealed significant differences in SNB, pogonion-nasion A point perpendicular (Pg-NA Per), sum of interior angles, S-Go, condylion-A point (Co-A), condyliongnathion (Co-Gn), maxilla-mandibular difference, lower1-mandibular plane angle (IMPA), Wits, lower lip-E plane (LL-E), UL-E, upper lip-A point (ULA), lower lip-A point (LLA), soft tissue pogonion (ST 'Pg), overjet and overbite values $\mathrm{P}<0.05$. Whereas significant difference was found in SNB, IMPA, ULA, LLA, ST' Pg and overbite between TB and control groups, other differences were found between $\mathrm{MB}$ and the control group. The results are shown in Table 3. 
Table 2. Comparison of treatment results between monoblock and twin-block groups

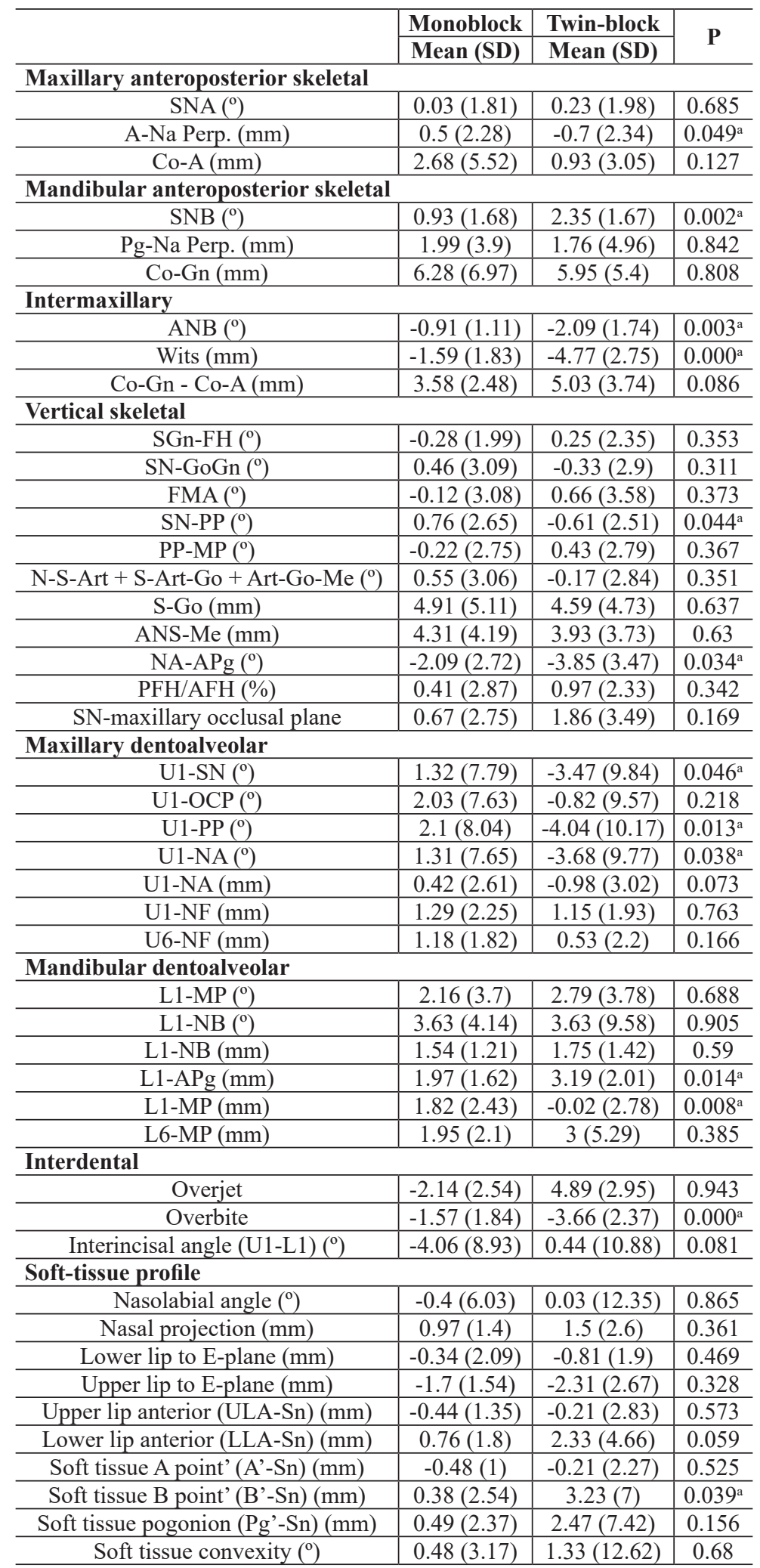

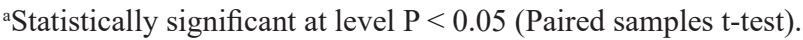

$\mathrm{S}=$ sella; $\mathrm{N}=$ nasion; $\mathrm{A}=\mathrm{A}$ Point (subspinale); $\mathrm{B}=\mathrm{B}$ point (supramentale); $\mathrm{SNA}=$ sella-nasion- $\mathrm{A}$ point angle; $\mathrm{SNB}=$ sella-nasion-B point angle; $\mathrm{ANB}=\mathrm{A}$ point-nasion- $\mathrm{B}$ point angle; $\mathrm{Na}$ Perp = nasion perpendicular; $\mathrm{Pg}=$ pogonion; $\mathrm{Gn}=$ gnathion; $\mathrm{FH}=\mathrm{Frankfurt} \mathrm{horizontale}$; $\mathrm{Go}=$ gonion; $\mathrm{PP}=$ palatal plane; $\mathrm{MP}=$ mandibular plane; $\mathrm{Art}=$ articulare; $\mathrm{Me}=$ menton; $\mathrm{ANS}=$ anterior nasal spine; $\mathrm{Co}=\mathrm{condylion} ; \mathrm{Mx} /$ $\mathrm{Md}$ dif $=$ maxillomandibular difference; $\mathrm{PFH}=$ posterior facial height; $\mathrm{AFH}=$ anterior facial height; $\mathrm{OCP}=\mathrm{occlusal}$ plane; $\mathrm{U} 1=$ incisal edge of the maxillary incisor; L1 = incisal edge of the mandibular incisor; U6 = maxillary first molar; L6 = mandibular first molar NF = nasal floor; $\mathrm{Sn}=$ subnasale; ULA = upper lip anterior; LLA = lower lip anterior; A' = soft tissue subspinale; B' = soft tissue supramentale; Pg' = soft tissue pogonion. 
Table 3. Comparison of final cephalometric values among groups

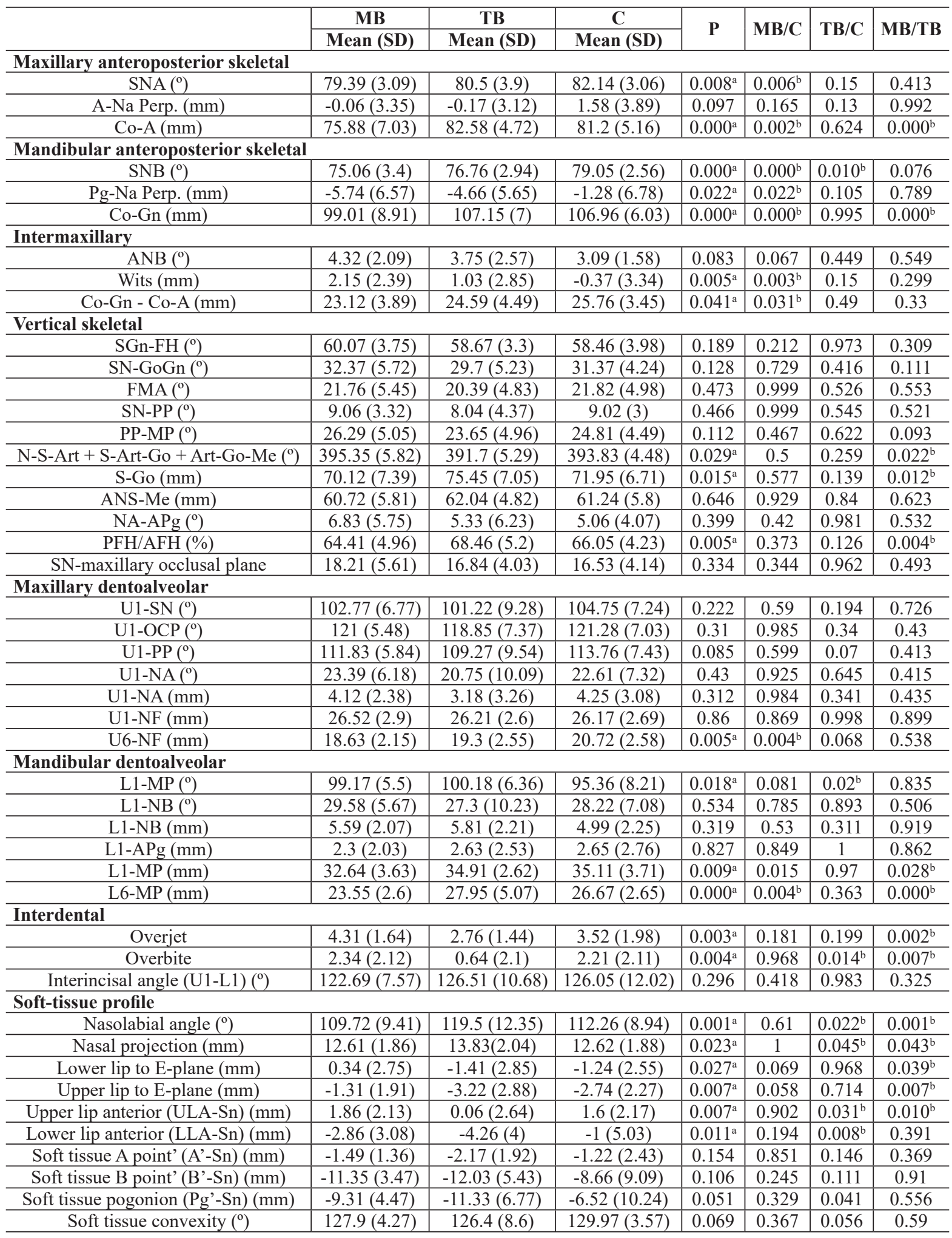

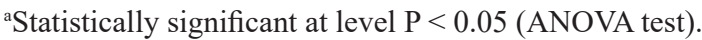

${ }^{\mathrm{b} S t a t i s t i c a l l y ~ s i g n i f i c a n t ~ a t ~ l e v e l ~} \mathrm{P}<0.05$ (Post Hoc Multiple Comparison; Tukey test).

$\mathrm{MB}=$ monoblock; $\mathrm{TB}=$ twin-block; $\mathrm{C}=$ control; $\mathrm{S}=$ sella; $\mathrm{N}=$ nasion; $\mathrm{A}=\mathrm{A}$ Point (subspinale); $\mathrm{B}=\mathrm{B}$ point (supramentale); $\mathrm{SNA}=$ sella-nasion-A point angle; $\mathrm{SNB}=$ sella-nasion-B point angle; $\mathrm{ANB}=\mathrm{A}$ point-nasion-B point angle; Na Perp = nasion perpendicular; $\mathrm{Pg}=$ pogonion; $\mathrm{Gn}=$ gnathion; $\mathrm{FH}=$ Frankfurt horizontale; $\mathrm{Go}=$ gonion; $\mathrm{PP}=$ palatal plane; $\mathrm{MP}=$ mandibular plane; $\mathrm{Art}=$ articulare; $\mathrm{Me}$ $=$ menton; $\mathrm{ANS}=$ anterior nasal spine; $\mathrm{Co}=$ condylion; $\mathrm{Mx} / \mathrm{Md}$ dif $=$ maxillomandibular difference; $\mathrm{PFH}=$ posterior facial height; $\mathrm{AFH}=$ anterior facial height; $\mathrm{OCP}=$ occlusal plane; $\mathrm{U} 1=$ incisal edge of the maxillary incisor; $\mathrm{L} 1=$ incisal edge of the mandibular incisor; U6 = maxillary first molar; L6 = mandibular first molar NF = nasal floor; $\mathrm{Sn}=$ subnasale; ULA = upper lip anterior; LLA = lower lip anterior; $\mathrm{A}^{\prime}=$ soft tissue subspinale; $\mathrm{B}^{\prime}=$ soft tissue supramentale; $\mathrm{Pg}^{\prime}=$ soft tissue pogonion. 


\section{DISCUSSION}

In our study, the effects of two different functional appliances on skeletal and dentofacial tissues were examined and, it was identified that the difference in the appliance design affects the treatment outcome.

Mandibular growth is an especially important factor in the development of Class II malocclusion. Although this might stem from the maxillary prognathism, this is the less common one [21]. Skeletal Class II malocclusions usually occur as a result of downward rotation of the mandible due to mandibular deficiency or vertical growth of the maxilla [26]. According to the initial cephalometric values of the patients included in our study, skeletal sagittal mandibular insufficiency was present in both groups with normal or reduced facial vertical and maxillary vertical values.

Functional appliances are frequently used in the treatment of Class II division 1 malocclusions due to mandibular retractions. Functional appliances produce orthopaedic and orthodontic changes with muscle forces resulting from the vertical and sagittal displacement of the mandible. Until today, different appliances have been designed to provide ease of use and patient comfort. The MB appliance is a difficult tool to cooperate with because of the space occupied in the mouth due to its size and the difficulty of speaking and swallowing. Considering that wear time is an important factor for the treatment efficacy, patient cooperation is essential for the prognosis of the treatment $\mathrm{P}<0.05$. It has been observed that the patients can eat and speak more easily by the TB appliance which is developed by Clark [27] and worn separately for the upper and lower jaws. The improvement and simplification of the appliance design has provided better acceptance of the appliance by the patients easily without any reduction in treatment effectiveness. In the light of this information, it is aimed to compare the effectiveness of two different appliance designs.

In the literature, stage of growth is suggested to be more important than chronological age of patients for the success of functional treatment $[28,29]$. Williams [30] reported that the use of wrist radiographs was the most reliable method to determine the growth progression as body and face growth occurs in the same developmental period. Cervical vertebrae as well as wrist bones would also be useful in determining the stage of growth and Lamparski [31] argued that cervical vertebrae were as valid and reliable as the hand-wrist region in determining bone age. Hassel et al. [르] concluded skeletal maturation level of the individual and thus the amount of growth potential to be estimated as shapes of the cervical vertebrae change at each stage of skeletal growth. In recent years, the use of cervical vertebrae has been advocated by using cephalometric radiographs as a diagnostic record in orthodontics instead of wrist radiographs in order to reduce radiation exposure of the patients. However, Koçak et al. [33] concluded that, the most reliable result for both sexes was obtained with hand-wrist assessments for the determination of stage of growth in individuals with skeletal Class II malocclusion in her thesis about the correlation of hand-wrist, cervical vertebrae, and tooth development in terms of malocclusions. For this reason, it was taken into consideration that the individuals included in the study were in the developmental period according to the hand-wrist radiographs [33].

When the intra-group variables were examined, statistically significant changes were observed in skeletal, dental, and soft tissue values in both groups. In both design groups, malocclusion improved as a result of treatment. In 1999, Tümer and Gültan [34] compared the effects of MB and TB appliance and found no statistically significant difference between sagittal changes in MB and TB groups. Similar results were found by Jena et al. [25] in their study comparing the skeletal and dentoalveolar effects of TB and bionator (B) devices in the treatment of Class II division 1 malocclusions. When the mandible is pushed forward by the functional appliances, the reaction force is distal to the maxilla and mesial growth is limited. Jena et al. [25] reported that devices did not effectively limit the growth in the maxilla compared to the control group, however, TB was more effective than B. Mandibular progression was reported to occur in TB, B and control groups, (5.02 mm, $4.42 \mathrm{~mm}$ and $3.37 \mathrm{~mm}$, respectively), but no significant difference was found between groups. In our study, the increase in $\mathrm{SNB}\left(\mathrm{TB}=2.35^{\circ}\right.$; $\left.\mathrm{MB}=0.93^{\circ}\right)$ and decrease in A-Na Perp $(\mathrm{TB}=$ $-0.7 \mathrm{~mm} ; \mathrm{MB}=0.5 \mathrm{~mm}$ ) in $\mathrm{TB}$ group were statistically significant compared to MB. Accordingly, it can be suggested that TB appliance causes more mandible growth stimulation and more maxillary growth inhibition than $\mathrm{MB}$ appliance. A significant decrease in the maxillary depth angle in the TB group, which is one of the findings of our studies, supports this hypothesis. When compared with the control group, it was found that the skeletal sagittal values obtained with the TB appliance were closer to those of the skeletal class I individuals.

In the MB group, the upper incisors were proclined (upperl-SN $=1.32^{\circ}$ ), and in the TB group, they were 
retroclined (upper1-SN $=-3.47^{\circ}$ ) and the difference in the incisors was statistically significant between two groups $(\mathrm{P}=0.046)$. This difference might be related to the backward effect of the TB appliance on the maxilla. Similar changes were observed in the lower incisor positions in both groups (IMPA: $\mathrm{TB}=2.79^{\circ} ; \mathrm{MB}=2.16^{\circ}$ ). Our findings are consistent with the literature $[14,17,22,23]$. Similar amount of lower incision proclination and protrusion is thought to occur as the lower incisors contain acrylic coatings in both appliance designs. The decrease in the amount of overbite was found to be statistically significant in the TB group compared to MB in the study by Tümer and Gültan [34]. According to our findings, overbite was lower in TB group $(-3.66 \mathrm{~mm})$ compared to $\mathrm{MB}$ group $(-1.57 \mathrm{~mm})$ and this change was statistically significant. There are other studies in the literature that support our finding. This decrease is thought to be caused by the increase in proclination of the incisors in TB group.

At the same time, L1-MP distance, representing the change in the vertical position of the lower incisors was decreased in TB group compared to MB group, the decrease was statistically significant. In this case, it is thought to have an effect on the reduction of overbite in TB group. Although there was a significant increase in the pre- and post-treatment mandibular plane angle ( $\mathrm{SN} / \mathrm{GoGn})$ in $\mathrm{MB}$ group, a decrease in TB group was observed. During treatment, the abrasions from the posterior region of the MB appliance may have increased the upper alveolar process (U6-NF), lower alveolar process (L6-MP) and might have resulted in an increase in vertical dimensions. In TB group, only the increase in upper posterior alveolar height was found to be significant and no significant change was observed in the lower posterior region. The TB appliance was also abraded in the posterior region during treatment; however, considering the decrease in vertical height and the change in the lower alveolar region, it was thought that the abrasions were made in a smaller amount compared to MB appliance. If the abrasions are low or not made, the TB appliance can have a posterior biteblock effect [14].

It is thought that the forward movement of the lower lip and jaw tip is the result of the forward movement of the mandible with functional treatment. However, it is a matter of debate how the movement of the upper incisors would reflect on the lips [35]. Changes in soft tissue reflecting positively to the profile were observed in both groups. There was a significant change in all soft tissue values in $\mathrm{MB}$ group compared to the pre- and post-treatment data, whereas no significant change was observed in ST B' and ST convexity values in TB group. When the endof-treatment data were compared, ST B' and LLA values presented a statistically significant increase in TB group compared to MB. There was a statistically significant difference in the nasolabial angle, $\mathrm{ST}^{\prime} \mathrm{Pg}$ and LLA values in the TB group in comparison with the control group, whereas there was no statistically significant difference in the soft tissue values in the MB group. This difference is thought to be caused by the soft tissue values in the TB group compared to $\mathrm{MB}$ when the initial soft tissue changes of TB and MB are compared.

The difference in treatment results might stem from the differences in the wear time of appliances. Jena et al. [25] reported that the mandibular changes were more common in $\mathrm{TB}$ group and this was attributed to the increased wear time ( $\mathrm{TB}=24$ hours; $\mathrm{B}=$ 15 hours). However, the retrospective design and inability to check whether patients adhered to the instructions about the wear time are among the limitations of our study. In future clinical studies, micro-sensors can be placed on the devices that provide use information, and the daily use times of the appliance can be standardized. Therefore, the patients who do not adhere to treatment instructions can be excluded from the study and more accurate results can be obtained.

\section{CONCLUSIONS}

The findings of the present study indicate:

1. Twin-block appliance has caused further forward movement of the mandible and backward movement of the maxilla in the sagittal direction compared to monoblock appliance.

2. Following the functional treatment, the mandibular skeletal position is located posteriorly compared to the control group.

3. Both appliance designs have caused similar increase in the skeletal vertical size.

4. While different effects were observed in upper incisors with different appliance designs, similar effects were observed for the lower incisors.

5. Following the treatment with twin-block, the upper lip was found to be displaced backward compared to other two groups.

\section{ACKNOWLEDGMENTS AND DISCLOSURE STATEMENTS}

The authors report no conflicts of interest related to this study. 


\section{REFERENCES}

1. Angle EH. Treatment of Malocclusion of the Teeth: Angle's System. Greatly Enl. and Entirely Rewritten, with Six Hundred and Forty-one Illustrations. Philadelphia: S.S. White dental manufacturing Co.; 1907.

2. Gelgör IE, Karaman AI, Ercan E. Prevalence of malocclusion among adolescents in central anatolia. Eur J Dent. 2007 Jul;1(3):125-31. [Medline: 19212555] [PMC free article: 2638238] [doi: 10.1055/s-0039-1698327]

3. Mossey PA. The heritability of malocclusion: part 2. The influence of genetics in malocclusion. Br J Orthod. 1999 Sep;26(3):195-203. [Medline: 10532158] [doi: 10.1093/ortho/26.3.195]

4. Bishara SE. Class II malocclusions: diagnostic and clinical considerations with and without treatment. Semin Orthod. 2006 Mar;12(1):11-24. [doi: 10.1053/j.sodo.2005.10.005]

5. Pancherz H, Zieber K, Hoyer B. Cephalometric characteristics of Class II division 1 and Class II division 2 malocclusions: a comparative study in children. Angle Orthod. 1997;67(2):111-20. [Medline: 9107375]

6. Varrela J. Early developmental traits in class II malocclusion. Acta Odontol Scand. 1998 Dec;56(6):375-7. [Medline: 10066120] [doi: 10.1080/000163598428356]

7. Drelich RC. A Cephalometric Study of Untreated Class II, Division 1 Malocclusion1. Angle Orthod. 1948 Jul;18(3):70-5.

8. Freitas MR, Santos MA, Freitas KM, Janson G, Freitas DS, Henriques JF. Cephalometric characterization of skeletal Class II, division 1 malocclusion in white Brazilian subjects. J Appl Oral Sci. 2005 Jun;13(2):198-203. [Medline: 20924549] [doi: 10.1590/S1678-77572005000200020]

9. Sayin MO, Türkkahraman H. Malocclusion and crowding in an orthodontically referred Turkish population. Angle Orthod. 2004 Oct;74(5):635-9. [Medline: 15529498]

10. Akarsu B, Kocadereli I. Cephalometric Morphology of Turkish Children with Class II Malocclusion. Turk J Orthod. 2010 Aug;23(2):123-35. [doi: 10.13076/1300-3550-23-2-123]

11. Fisk GV, Culbert MR, Grainger RM, Hemrend B, Moyers R. The morphology and physiology of distoclusion: A summary of our present knowledge. Am J Orthod Dent Orthop. 1953 Jan;39(1):3-12. [doi: 10.1016/0002-9416(53)90092-X]

12. Ishii N, Deguchi T, Hunt NP. Craniofacial morphology of Japanese girls with Class II division 1 malocclusion. J Orthod. 2001 Sep;28(3):211-5. [Medline: 11504898] [doi: 10.1093/ortho/28.3.211]

13. Toth LR, McNamara JA Jr. Treatment effects produced by the twin-block appliance and the FR-2 appliance of Fränkel compared with an untreated Class II sample. Am J Orthod Dentofacial Orthop. 1999 Dec;116(6):597-609. [Medline: 10587592] [doi: 10.1016/S0889-5406(99)70193-9]

14. Näpänkangas R, Raunio A, Sipilä K, Raustia A. Effect of mandibular advancement device therapy on the signs and symptoms of temporomandibular disorders. J Oral Maxillofac Res. 2013 Jan 1;3(4):e5. [Medline: 24422023] [PMC free article: 3886094] [doi: 10.5037/jomr.2012.3405]

15. Bishara SE, Ziaja RR. Functional appliances: a review. Am J Orthod Dent Orthop. 1989 Mar;95(3):250-8. [doi: 10.1016/0889-5406(89)90055-3]

16. Baltromejus S, Ruf S, Pancherz H. Effective temporomandibular joint growth and chin position changes: Activator versus Herbst treatment. A cephalometric roentgenographic study. Eur J Orthod. 2002 Dec;24(6):627-37. [Medline: 12512780] [doi: 10.1093/ejo/24.6.627]

17. Varlik SK, Gültan A, Tümer N. Comparison of the effects of Twin Block and activator treatment on the soft tissue profile. Eur J Orthod. 2008 Apr;30(2):128-34. [Medline: 18281262] [doi: 10.1093/ejo/cjm121]

18. Marşan G. Effects of activator and high-pull headgear combination therapy: skeletal, dentoalveolar, and soft tissue profile changes. Eur J Orthod. 2007 Apr;29(2):140-8. [Medline: 17488997] [doi: 10.1093/ejo/cjm003]

19. Nelson C, Harkness M, Herbison P. Mandibular changes during functional appliance treatment. Am J Orthod Dentofacial Orthop. 1993 Aug;104(2):153-61. [Medline: 8338068] [doi: 10.1016/S0889-5406(05)81005-4]

20. Oztürk Y, Tankuter N. Class II: a comparison of activator and activator headgear combination appliances. Eur J Orthod. 1994 Apr;16(2):149-57. [Medline: $\underline{8005202}$ ] [doi: $10.1093 /$ jo $/ 16.2 .149]$

21. Wigal TG. Long-term follow-up of patients treated with the edgewise crowned Herbst appliance in the mixed dentition [dissertation]. Morgantown (WV); West Virginia University; 2008. [doi: 10.33915/etd.2650]

22. Sidlauskas A. The effects of the Twin-block appliance treatment on the skeletal and dentolaveolar changes in Class II Division 1 malocclusion. Medicina (Kaunas). 2005;41(5):392-400. [Medline: 15947523]

23. Baysal A, Uysal T. Dentoskeletal effects of Twin Block and Herbst appliances in patients with Class II division 1 mandibular retrognathy. Eur J Orthod. 2014 Apr;36(2):164-72. [Medline: 24663007] [doi: 10.1093/ejo/cjt013]

24. Illing HM, Morris DO, Lee RT. A prospective evaluation of Bass, Bionator and Twin Block appliances. Part I--The hard tissues. Eur J Orthod. 1998 Oct;20(5):501-16. [Medline: 9825553] [doi: 10.1093/ejo/20.5.501]

25. Jena AK, Duggal R, Parkash H. Skeletal and dentoalveolar effects of Twin-block and bionator appliances in the treatment of Class II malocclusion: a comparative study. Am J Orthod Dentofacial Orthop. 2006 Nov;130(5):594-602. [Medline: 17110256 ] [doi: $10.1016 /$ j.ajodo.2005.02.025]

26. Moyers RE. Handbook of Orthodontics. 4th ed. Chicago: Year Book Medical Pub; 1988.

27. Clark WJ. Twin Block Functional Theraphy: Applications in Dentofacial Orthopedics. 2nd ed. London, Mosby; 2002. 
28. Fishman LS. Radiographic evaluation of skeletal maturation. A clinically oriented method based on hand-wrist films. Angle Orthod. 1982 Apr;52(2):88-112. [Medline: 6980608]

29. Suda N, Ishii-Suzuki M, Hirose K, Hiyama S, Suzuki S, Kuroda T. Effective treatment plan for maxillary protraction: is the bone age useful to determine the treatment plan? Am J Orthod Dentofacial Orthop. 2000 Jul;118(1):55-62. [Medline: 10893473] [doi: 10.1067/mod.2000.104491]

30. Williams BH. Anterior vertical incremental facial growth: its effects in class II treatment. Angle Orthod. 1980 Jul;50(3): 179-88. [Medline: 6931503]

31. Lamparski DG. Skeletal age assessment utilizing cervical vertebrae [master's thesis]. Pittsburgh (PA): University of Pittsburgh; 1972.

32. Hassel B, Farman AG. Skeletal maturation evaluation using cervical vertebrae. Am J Orthod Dentofacial Orthop. 1995 Jan;107(1):58-66. doi: 10.1016/s0889-5406(95)70157-5. Erratum in: Am J Orthod Dentofacial Orthop 1995 Jun;107(6):19. [Medline: 7817962] [doi: 10.1016/S0889-5406(95)70157-5]

33. Koçak T, Akan B. Assessment of maturation indicators in individuals with different skeletal malocclusion. J Orofac Orthop. 2021 May;82(3):187-197. English. [Medline: 33725143] [doi: 10.1007/s00056-021-00286-2]

34. Tümer N, Gültan AS. Comparison of the effects of monoblock and twin-block appliances on the skeletal and dentoalveolar structures. Am J Orthod Dentofacial Orthop. 1999 Oct;116(4):460-8. [Medline: 10511676] [doi: 10.1016/S0889-5406(99)70233-7]

35. Roos N. Soft-tissue profile changes in class II treatment. Am J Orthod. 1977 Aug;72(2):165-75. [Medline: 268147] [doi: $10.1016 / 0002-9416(77) 90057-4$ ]

\section{To cite this article:}

Akan B, Erhamza TS.

Does Appliance Design Affect Treatment Outcomes of Class II Division 1 Malocclusion? A Two-Center Retrospective Study J Oral Maxillofac Res 2021;12(2):e4

URL: http://www.ejomr.org/JOMR/archives/2021/2/e4/v12n2e4.pdf

doi: $10.5037 /$ jomr.2021.12204

Copyright (C) Akan B, Erhamza TS. Published in the JOURNAL OF ORAL \& MAXILLOFACIAL RESEARCH (http://www. ejomr.org), 30 June 2021.

This is an open-access article, first published in the JOURNAL OF ORAL \& MAXILLOFACIAL RESEARCH, distributed under the terms of the Creative Commons Attribution-Noncommercial-No Derivative Works 3.0 Unported License, which permits unrestricted non-commercial use, distribution, and reproduction in any medium, provided the original work and is properly cited. The copyright, license information and link to the original publication on (http://www.ejomr.org) must be included. 